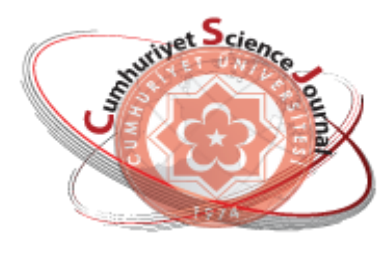

e-ISSN: $2587-246 X$

ISSN: $2587-2680$

\section{Cumburiyet Scionce Journal $\operatorname{csg}$}

Cumhuriyet Sci. J., Vol.40-3 (2019) 624-639

\title{
Evaluation of radioactive pollution in sediment samples of Borçka Dam Lake, Turkey Murat SiRIN
} Recep Tayyip Erdoğan University, Department of Physics, 53100, Rize, Turkey

\begin{abstract}
In this research, the concentrations of natural (226Ra, 232Th and 40K) and anthropogenic (137Cs) radionuclides were measured in sediment samples collected from the Borçka Dam Lake using a high purity germanium detector (HPGe). The activity values ranged from 4.79-21.46, 9.36-20.65, 238.01-721.26 and 0.79$6.81 \mathrm{~Bq} \mathrm{~kg}-1$ for 226Ra, 232Th, 40K and 137Cs respectively. The average 226Ra, 232Th and 40K activity concentrations calculated for the sediment samples were found to be lower compared to world average values reported by UNSCEAR. In addition, radiological hazard indices were determined and compared with the international permissible values. The results of this study revealed that there is no significant health risk for people exposed to sediment samples in this region.
\end{abstract}

Keywords: Borçka Dam Lake, Radioactivity, Sediment, Lifetime cancer risk.

\section{Türkiye’de Borçka Baraj Gölünün Sediment Örneklerinde Radyoaktif Kirliliğin Değerlendirmesi}

\begin{abstract}
Özet. Bu araştırmada, Borçka Baraj Gölü’nden toplanan sediment örneklerinde doğal (226Ra, 232Th ve 40K) ve yapay (137Cs) radyonüklidlerin konsantrasyonları yüksek saflıkta germanyum dedektörü (HPGe) kullanılarak ölçülmüştür. Aktivite değerleri 226Ra, 232Th, 40K ve 137Cs için sırasıyla 4.79-21.46, 9.36-20.65, 238.01-721.26 ve 0.79-6.81 Bq kg-1 aralığında değişmiştir. Sediment örnekleri için hesaplanan ortalama 226Ra, 232Th ve 40K aktivite konsantrasyonları UNSCEAR tarafindan rapor edilen dünya ortalaması değerlerinden daha düşük bulunmuştur. Ayrıca, radyolojik tehlike indisleri belirlenmiş ve uluslararası izin verilen değerlerle karşılaştırılmıştır. Bu çalışmanın sonuçları, bu bölgedeki sediment örneklerine maruz kalan insanlar için önemli bir sağlık riski olmadığını ortaya çıkarmıştır.
\end{abstract}

Anahtar Kelimeler: Borçka Baraj Gölü, Radyoaktivite, Sediment, Yaşam boyu kanser riski.

\section{INTRODUCTION}

Naturally radioisotopes (226Ra, 232Th, and 40K) are connected with rock, sand, soil and sediments in an environment. The man-made radionuclides left in our environment come from anthropogenic sources such as nuclear weapons tests and nuclear accidents [1]. Human source radionuclides, accidents in nuclear reactors, and fission products resulting from nuclear tests or industrial activities are also sources of pollution that may have a significant impact on the water environment [2]. Natural and anthropogenic radioisotopes can be transported to different 
distances after different processes and finally accumulate in sediment particles [3-4]. Due to the Chernobyl nuclear power plant accident, the Marmara and the Black Sea region of Turkey was contaminated with high artificial radioisotopes [5]. After the Chernobyl accident, the northeastern of Turkey in particular has been contaminated by artificial radionuclides. The radioactive cloud resulting from the nuclear accident arrived the territory of Turkey on 5 May 1986 and the country's different regions and ecosystems significantly polluted [6]. Therefore, the determination of the distribution of natural and anthropogenic radionuclides in the environmental environment is extremely important for environmental monitoring, nuclear protection and nuclear forensic studies [5].

It is stated that the river sediments are the wear products of the rocks and they have mineralogical properties of the original rock formation. Sediments play an important role in aquatic radioecology, because they carry and accumulate pollutants (radioactivity, heavy metal, etc.) in the environmental area. Therefore, the investigation of radioactivity levels in sediments in rivers and lakes provides useful information related to environmental pollution. For these reasons, monitoring and determining the activity concentrations and gamma-dose ratios of radionuclides is an important issue for humanity [7].

Rivers play an important role in transporting sedimental particles and organic matter from land to seas, but man-made obstacles such as dams prevent the transporting of these substances to marine environment and so these particulate matters accumulate at the bottom of the Dam lakes.

In time, sediments deposited at the bottom of the lake are an important component for monitoring the change of radioactive pollution in the region. In addition, radionuclides accumulating in the lake contaminate the water environment in which they are in contact. Dam waters are frequently used to irrigate agricultural lands located in the nearby area and therefore the determination of radioactive pollution in sediment samples in lake environment shows the importance of this research study [8].

To determine radioactivity levels at the dam lake and river sediments, some investigations have been carried out in Turkey [1, 8-11]. However, the studies conducted to determine the radioactivity levels of the sediment samples of the Dam lakes are limited in Turkey. Therefore, in the present study, the activity concentrations of natural $\left({ }^{226} \mathrm{Ra},{ }^{232} \mathrm{Th}\right.$ and $\left.{ }^{40} \mathrm{~K}\right)$ and anthropogenic $\left({ }^{137} \mathrm{Cs}\right)$ radionuclides in sediment samples collected from Borçka Dam Lake have been surveyed. Besides, radiological hazard indices such as the radium equivalent activity $\left(\mathrm{Ra}_{\mathrm{eq}}\right)$, the external hazard index $\left(\mathrm{H}_{\mathrm{ex}}\right)$, the absorbed dose rate in air (D), the annual effective dose equivalent (AEDE) and the excess lifetime cancer risk (ELCR) were calculated and compared with the international permissible values. 


\section{MATERIALS AND METHODS}

\subsection{Study area and sampling}

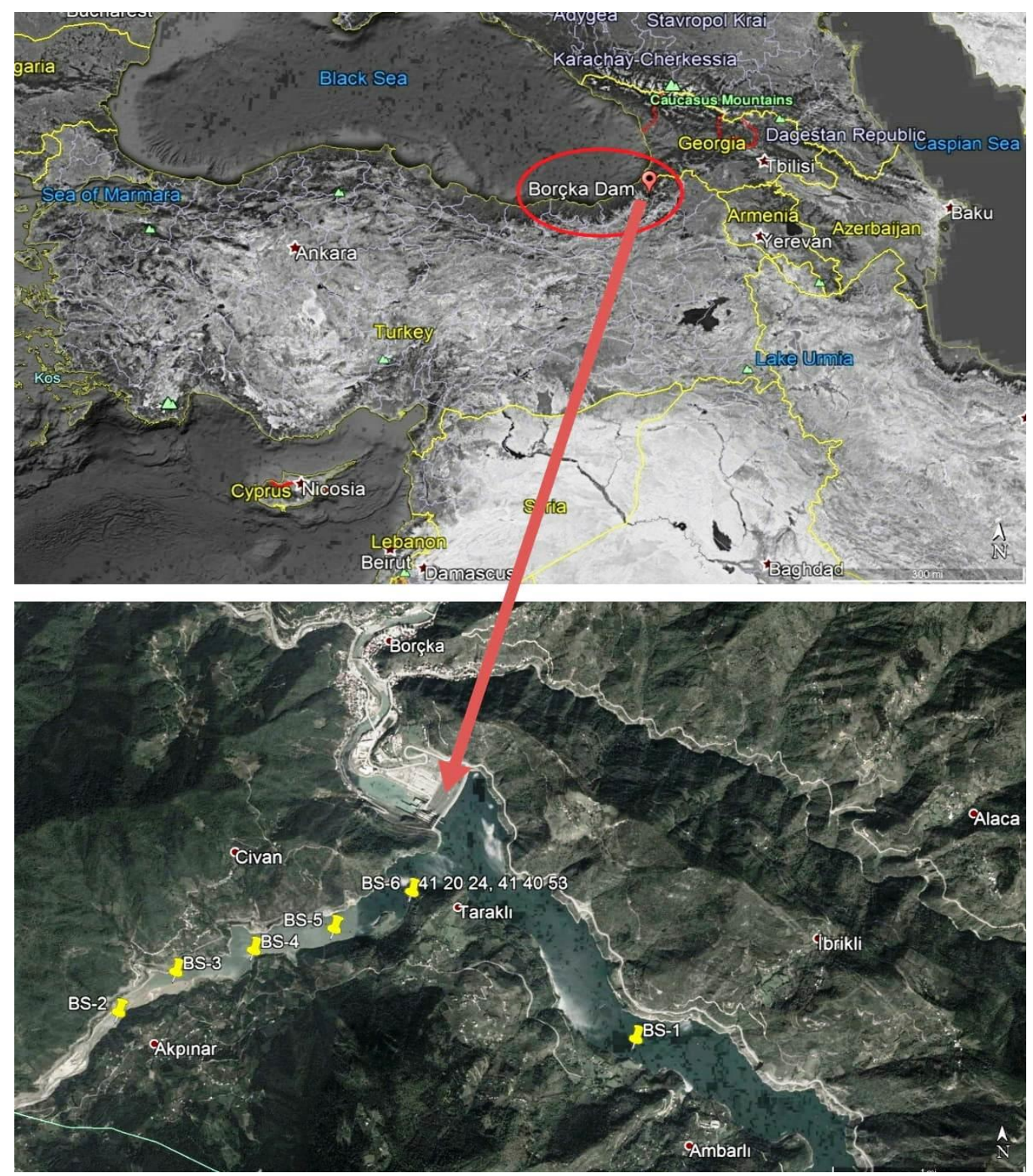

Figure 1. The sampling stations in the Borçka Dam Lake (Gedik et al., 2018)

Borçka Dam is a dam built on the Çoruh River in Artvin between 1998 and 2005 to produce energy. Turkey's Northeast Anatolia region is located on the Coruh River Basin is located in the lower Coruh basin. It is producing hydroelectric power. The body volume of the dam, which is the type of the soil trunk filling, is $7.785 .000 \mathrm{~m}^{3}$, the height from the stream bed is $86,00 \mathrm{~m}$, the lake volume is $419,00 \mathrm{hm}^{3}$ in the normal water level, and the water area in the normal water level is $10.84 \mathrm{~km}^{2}$. The dam produces energy of $1.039 \mathrm{GWh}$ per year with $300 \mathrm{MW}$ power. 
In this research, three lake sediment samples were collected from each of the six sampling points determined in Borçka Dam Lake in April 2016. The sampling stations in the Borçka Dam Lake are presented in Figure 1 and the coordinates of the sampling points and some physico-chemical properties of the sediment samples collected from Borçka Dam Lake are given in Table 1. The coordinates of all sampling points were recorded using a GPS tool. Approximately $1-2 \mathrm{~kg}$ of sediment samples were collected from each sampling point by means of an Ekman-Birge sampler; then the collected samples were transferred to nylon bags and the bags were tightly sealed by labeling them to prevent mixing and contamination of the samples. Subsequently, all samples were transferred to the cold chain box and transported to the laboratory for the necessary analyses. [12-13]. 
Sirin / Cumhuriyet Sci. J., Vol.40-3 (2019) 624-639

Table 1. The coordinates of sampling points and some physico-chemical properties in sediment samples collected from Borçka Dam Lake.

\begin{tabular}{|c|c|c|c|c|c|c|c|}
\hline $\begin{array}{l}\text { Sampling } \\
\text { location }\end{array}$ & $\begin{array}{l}\text { North } \\
\text { latitude }\end{array}$ & $\begin{array}{c}\text { East } \\
\text { longitude }\end{array}$ & $\begin{array}{l}\text { Sampling depth } \\
(\mathrm{m})\end{array}$ & pH & Sand (\%) & Silt+Clay (\%) & $\begin{array}{c}\text { Total organic } \\
\text { carbon (TOC) } \\
(\%)\end{array}$ \\
\hline BS-1 & $41^{\circ} 19^{\prime} 36^{\prime \prime} \mathrm{N}$ & $41^{\circ} 42^{\prime} 28^{\prime \prime} \mathrm{E}$ & 35 & 7.36 & 87.45 & 12.55 & 1.84 \\
\hline BS-2 & $41^{\circ} 19^{\prime} 45^{\prime \prime} \mathrm{N}$ & $41^{\circ} 38^{\prime} 49^{\prime \prime} \mathrm{E}$ & 1.3 & 8.17 & 98.13 & 1.87 & 0.79 \\
\hline BS-3 & $41^{\circ} 19^{\prime} 58^{\prime \prime} \mathrm{N}$ & $41^{\circ} 39^{\prime} 13^{\prime \prime} \mathrm{E}$ & 3.8 & 8.01 & 92.68 & 7.32 & 1.24 \\
\hline BS-4 & $41^{\circ} 20^{\prime} 05^{\prime \prime} \mathrm{N}$ & $41^{\circ} 39^{\prime} 46^{\prime \prime} \mathrm{E}$ & 7.6 & 7.90 & 21.57 & 78.43 & 1.62 \\
\hline BS-5 & $41^{\circ} 20^{\prime} 12^{\prime \prime} \mathrm{N}$ & $41^{\circ} 40^{\prime} 20^{\prime \prime} \mathrm{E}$ & 22.4 & 7.89 & 31.22 & 68.78 & 1.67 \\
\hline BS-6 & $41^{\circ} 20^{\prime} 24^{\prime \prime} \mathrm{N}$ & $41^{\circ} 40^{\prime} 53^{\prime \prime} \mathrm{E}$ & 33.7 & 7.90 & 89.92 & 10.08 & 1.19 \\
\hline
\end{tabular}




\subsection{Characterization of sediments}

Granulometric analysis of the samples was performed with the help of Retsch brand (Germany) AS 200 model vibratory sieve shaker. After Granulometric analysis, sediments were classified as sand $(0.063-2 \mathrm{~mm})$ and silt + clay $(<0.063 \mathrm{~mm})$ based on grain size. To determine the $\mathrm{pH}$ values of the sediment samples, the samples were sieved by a $2 \mathrm{~mm}$ sieve and then left to dry in the oven at $105{ }^{\circ} \mathrm{C}$. Then $10 \mathrm{~g}$ of sediment sample was placed in the flask and $50 \mathrm{~mL}$ of deionized water $(1$ sediment: 5 water) was added. After the prepared mixture is stirred for about 1 hour, measurements were made with the $\mathrm{pH}$ probe in the YSI brand multi-parameter probe [13]. A Shimadzu SSM5000A Total Organic Carbon Analyzer device was used to measure the total organic carbon (TOC) level of the sediment samples. The TOC content in the samples was determined by the difference between total carbon (TC) and inorganic carbon (IC) values [14].

\subsection{Sample preparation for activity measurements}

After the sediment samples were transferred to the laboratory, the first stone particles and visible impurities were removed. Each sample of the sediment was then homogenized in a mortar and allowed to dry in an oven at $105^{\circ} \mathrm{C}$ for 24 hours to remove moisture. Dried samples were sieved with a 400 mesh $(63 \mu \mathrm{m})$ sieve. Approximately $118 \mathrm{~g}$ of each sample was placed in polyethylene containers with cylindrical screw cap $(5.5 \mathrm{~cm}$ diameter and $5 \mathrm{~cm}$ height) for gamma measurement and sealed tightly [15]. Before starting the gamma activity analysis, the vessels were kept closed for four weeks to achieve a balance between ${ }^{226} \mathrm{Ra}$ and the short-lived generation [16].

\subsection{Gamma spectrometry measurement}

The activity levels of ${ }^{226} \mathrm{Ra},{ }^{232} \mathrm{Th},{ }^{40} \mathrm{~K}$ and ${ }^{137} \mathrm{Cs}$ in all samples were measured using a coaxial HPGe detector (Ortec, GEM55P4-95 model). Detailed explanations about the measurement system are previously presented elsewhere $[12,16]$.

The gamma-energy lines of $351.9 \mathrm{keV}\left({ }^{214} \mathrm{~Pb}\right)$ and $609.3 \mathrm{keV}\left({ }^{214} \mathrm{Bi}\right)$ were used to represent the ${ }^{226} \mathrm{Ra}$ series, while $911.1 \mathrm{keV}\left({ }^{228} \mathrm{Ac}\right)$ and $583.1 \mathrm{keV}\left({ }^{208} \mathrm{Tl}\right)$ were used to represent the ${ }^{232} \mathrm{Th}$ series. The activity values of of ${ }^{40} \mathrm{~K}$ and ${ }^{137} \mathrm{Cs}$ were determined using their peaks at $1460.8 \mathrm{keV}$ and 661.6 $\mathrm{keV}$, respectively. In the calculation of activity, dry weight ( $\mathrm{dw}$ ) was taken into account for all samples $[12,17]$.

The activity concentrations of the studied radionuclides $\left({ }^{226} \mathrm{Ra},{ }^{232} \mathrm{Th},{ }^{40} \mathrm{~K}\right.$ and $\left.{ }^{137} \mathrm{Cs}\right)$ in the samples measured by utilizing the equation given below were determined:

$$
\mathrm{C}=\frac{\mathrm{N}}{\varepsilon . \mathrm{P} \gamma \text {.t.m }}\left(\mathrm{Bq} \mathrm{kg}^{-1)}\right.
$$


where $\mathrm{N}$ is the net count rate of the gamma ray; $\varepsilon$ is the photo peak yield of the detector, $\mathrm{P} \gamma$ is the absolute transition of gamma decay, $\mathrm{t}$ is the counting time in seconds, and $\mathrm{m}$, the mass of the sample from the kilogram unit.

The MDA of the current gamma system was determined using the equation presented below [18]:

$$
\mathrm{MDA}=\frac{\sigma \sqrt{\mathrm{B}}}{\varepsilon . \mathrm{I}_{\gamma} \cdot \mathrm{t.w}}
$$

where MDA is in $\mathrm{Bq} \mathrm{kg}^{-1}, \sigma$ is the statistical coverage factor, which is equal to 1.645 (confidence level 95\%), and B is the background value for a certain radionuclide [12]. The MDA for the studied radionuclides was calculated as $0.16,0.24,1.69$ and $0.02 \mathrm{~Bq} \mathrm{~kg}^{-1}$ for ${ }^{226} \mathrm{Ra},{ }^{232} \mathrm{Th},{ }^{137} \mathrm{Cs}$ and ${ }^{40} \mathrm{~K}$, respectively. In order to determine the accuracy of the measurement system, an example of the certified reference material IAEA-447 was read in the system in triplicate in a similar manner to the samples. In the reference sample, the concentrations of ${ }^{226} \mathrm{Ra},{ }^{232} \mathrm{Th},{ }^{137} \mathrm{Cs}$ and ${ }^{40} \mathrm{~K}$ were given as $25.04,37.3,371.11$ and $550 \mathrm{~Bq} \mathrm{~kg}^{-1}$, respectively. For the measurement system, ${ }^{226} \mathrm{Ra},{ }^{232} \mathrm{Th},{ }^{137} \mathrm{Cs}$ and ${ }^{40} \mathrm{~K}$ values were calculated as $23.96,35.7,362.55$ and $521 \mathrm{~Bq} \mathrm{~kg}^{-1}$, respectively. Accuracy, expressed as recovery of the reference substance, was found in the range of $95-98 \%$ for all radionuclides.

\section{RESULTS AND DISCUSSION}

\subsection{Physiochemical properties of sediments}

The physico-chemical parameters determined in sediment samples are presented in Table 1. In the current study, it was found that the values of $\mathrm{pH}$, Sand, Silt+Clay, and TOC ranged between $7.36-8.17,21.57-98.13 \%, 1.87-78.43 \%$, and $0.79-1.84 \%$, respectively. The lowest $\mathrm{pH}$ and highest TOC content were determined at the BS-1 location. It is known that this station is under the influence of water culture and causes high organic substances due to uneaten feed, decayed plants and live wastes and feces in such areas [13].

\subsection{Natural radioactivity in sediment}

The activity concentrations of ${ }^{226} \mathrm{Ra},{ }^{232} \mathrm{Th}$ and ${ }^{40} \mathrm{~K}$ radionuclides detected in sediment samples gathered from Borçka Dam Lake are shown in Table 2. It was observed that the concentrations determined in this study ranged from 4.79 to $21.46 \mathrm{~Bq} \mathrm{~kg}^{-1}$ (the mean concentration of $12.19 \mathrm{~Bq}$ $\mathrm{kg}^{-1}$ ) for ${ }^{226} \mathrm{Ra}$, from 9.36 to $20.65 \mathrm{~Bq} \mathrm{~kg}^{-1}$ the mean concentration of $14.05 \mathrm{~Bq} \mathrm{~kg}^{-1}$ ) for ${ }^{232} \mathrm{Th}$, and from 238.01 to $721.26 \mathrm{~Bq} \mathrm{~kg}^{-1}$ (the mean concentration of $396.41 \mathrm{~Bq} \mathrm{~kg}^{-1}$ ) for ${ }^{40} \mathrm{~K}$. Also, the highest ${ }^{226} \mathrm{Ra}$ and ${ }^{40} \mathrm{~K}$ concentration were detected in the BS- 6 station, while the highest ${ }^{232} \mathrm{Th}$ concentration was detected in the BS-1 station 
Table 2. The activity concentrations of ${ }^{226} \mathrm{Ra},{ }^{232} \mathrm{Th},{ }^{137} \mathrm{Cs}$ and ${ }^{40} \mathrm{~K}$ in sediment samples of Borçka Dam Lake.

\begin{tabular}{|c|c|c|c|c|}
\hline $\begin{array}{c}\text { Sampling location } \\
(\mathrm{N}=18)\end{array}$ & ${ }^{226} \mathrm{Ra}$ & ${ }^{232} \mathrm{Th}$ & ${ }^{137} \mathrm{Cs}$ \\
\hline BS-1 & $14.01 \pm 0.49$ & $20.65 \pm 0.83$ & $6.81 \pm 0.34$ & $464.79 \pm 23.24$ \\
\hline BS-2 & $8.94 \pm 0.36$ & $9.36 \pm 0.56$ & $0.79 \pm 0.05$ & $238.01 \pm 9.52$ \\
\hline BS-3 & $4.79 \pm 0.24$ & $10.78 \pm 0.54$ & $1.03 \pm 0.06$ & $244.96 \pm 11.76$ \\
\hline BS-4 & $11.80 \pm 0.50$ & $14.14 \pm 0.57$ & $5.69 \pm 0.20$ & $343.58 \pm 13.03$ \\
\hline BS-5 & $12.16 \pm 0.61$ & $14.96 \pm 0.48$ & $5.76 \pm 0.26$ & $365.84 \pm 21.95$ \\
\hline BS-6 & $21.46 \pm 1.07$ & $14.40 \pm 0.94$ & $5.10 \pm 0.19$ & $721.26 \pm 46.88$ \\
\hline Range & $\mathbf{4 . 7 9 - 2 1 . 4 6}$ & $\mathbf{9 . 3 6 - 2 0 . 6 5}$ & $\mathbf{0 . 7 9 - 6 . 8 1}$ & $\mathbf{2 3 8 . 0 1 - 7 2 1 . 2 6}$ \\
\hline Mean & $\mathbf{1 2 . 1 9}$ & $\mathbf{1 4 . 0 5}$ & $\mathbf{4 . 2 0}$ & $\mathbf{3 9 6 . 4 1}$ \\
\hline
\end{tabular}

$(\mathrm{N}=$ Sampling size $)$

Moreover, the comparison of mean activity concentrations of the present study with published results in sediment samples is shown in Table 3 . The ${ }^{226} \mathrm{Ra}$ activity concentrations reported in the Van Lake [1], the Metiterranean Central Basin [19], the Altınkaya Dam Lake [8], the Derbent Dam Lake [8], the Kizilırmak Delta [11] and the Yangtze Estuary [20] are higher than our values, but those for the Deriner, Borçka and Muratlı Dam Lakes [10] and the Vaigai River [21] are not. The ${ }^{232} \mathrm{Th}$ levels reported in the in the Van Lake [1], the Metiterranean Central Basin [19], the Altınkaya Dam Lake [8], the Derbent Dam Lake [8], the Deriner, Borçka and Muratlı Dam Lakes [10], the Vaigai River [21], the Kizilırmak Delta [11] and the Yangtze Estuary [20] are higher than our values.

The ${ }^{40} \mathrm{~K}$ levels reported in the Van Lake [1], the Metiterranean Central Basin [19], the Altınkaya Dam Lake [8], the Derbent Dam Lake [8], the Deriner, Borçka and Muratlı Dam Lakes [10], the Vaigai River [21] and the Yangtze Estuary [20] are higher than our values, but those for the the Kizılırmak Delta [11] are not.

Consequently, the average values of ${ }^{226} \mathrm{Ra},{ }^{232} \mathrm{Th}$ and ${ }^{40} \mathrm{~K}$ found in Borçka Dam Lake are lower than the values recommended by UNSCEAR [22].

\subsection{Artificial radioactivity in sediment}

${ }^{137} \mathrm{Cs}$ activity concentrations determined in this study were presented in Table 2 . The mean activity concentrations of ${ }^{137} \mathrm{Cs}$ in sediment samples ranged from 0.79 to $6.81 \mathrm{~Bq} \mathrm{~kg}^{-1}$ (with a mean value of $4.20 \mathrm{~Bq} \mathrm{~kg}^{-1}$ ). When the mean activity concentrations were compared according to the sampling 
stations, the highest concentration $\left(6.81 \mathrm{~Bq} \mathrm{~kg}^{-1}\right)$ was detected in BS-1 and the lowest concentration $\left(0.79 \mathrm{~Bq} \mathrm{~kg}^{-1}\right)$ in the BS-2 station.

Furthermore, the results obtained in this study are compared with the results published in many studies in the literature as shown in Table 3. As shown in Table 3, the values reported in all previous studies for ${ }^{137} \mathrm{Cs}$ were higher than those of this study. 
Table 3. Comparison of mean activity concentrations of the present study with published results in sediment samples.

\begin{tabular}{|c|c|c|c|c|c|}
\hline Location & ${ }^{226} \mathrm{Ra}\left(\mathrm{Bq}^{-1}\right)$ & ${ }^{232} \mathrm{Th} \mathrm{Bqkg}^{-1}$ ) & ${ }^{137} \mathrm{Cs}\left(\mathrm{Bq} \mathrm{kg}^{-1}\right)$ & ${ }^{40} \mathrm{~K}\left(\mathrm{~Bq} \mathrm{~kg}^{-1}\right)$ & References \\
\hline $\begin{array}{c}\text { Turkey } \\
\text { (Van Lake) }\end{array}$ & 47.48 & 57.87 & 4.37 & 524 & {$[1]$} \\
\hline $\begin{array}{c}\text { Italy } \\
\text { (Mediterranean } \\
\text { Central Basin) } \\
\end{array}$ & 25.1 & 28.1 & & 809.8 & [19] \\
\hline $\begin{array}{c}\text { Turkey } \\
\text { (Altınkaya Dam Lake) }\end{array}$ & $19.5^{*}$ & 27.7 & & 460 & [8] \\
\hline $\begin{array}{c}\text { Turkey } \\
\text { (Derbent Dam Lake) }\end{array}$ & $18.8^{*}$ & 25.5 & & 365 & [8] \\
\hline $\begin{array}{c}\text { Turkey } \\
\text { (Deriner, Borçka and } \\
\text { Muratlı Dam Lakes) }\end{array}$ & $11.4^{*}$ & 18.3 & 13.5 & 510.2 & {$[10]$} \\
\hline $\begin{array}{c}\text { Indian } \\
\text { (Tamilnadu, Vaigai } \\
\text { River) } \\
\end{array}$ & $7.45^{*}$ & 33.81 & & 448.24 & {$[21]$} \\
\hline $\begin{array}{c}\text { Turkey } \\
\text { (K1zilırmak Delta) }\end{array}$ & $27.898^{*}$ & 14.184 & 9.890 & 62.372 & [11] \\
\hline $\begin{array}{c}\text { China } \\
\text { (Yangtze Estuary) }\end{array}$ & 24.3 & 40.9 & & 628 & {$[20]$} \\
\hline Worldwide & 35 & 30 & & 400 & {$[22]$} \\
\hline $\begin{array}{c}\text { Turkey } \\
\text { (Borçka Dam Lake) }\end{array}$ & 12.19 & 14.05 & 4.20 & 396.41 & $\begin{array}{l}\text { Present } \\
\text { Study }\end{array}$ \\
\hline
\end{tabular}

\subsection{Radiological hazard indices}

\subsubsection{Radium equivalent activity $\left(\mathbf{R a}_{\mathrm{eq}}\right)$ :}

Radium equivalent activity is calculated using the equation given below [23].

$$
R a_{e q}=C_{R a}+1.43 C_{T h}+0.077 C_{K}
$$

where, $\mathrm{C}_{\mathrm{Ra}}, \mathrm{C}_{\mathrm{Th}}$ and $\mathrm{C}_{\mathrm{K}}$ were the activities of ${ }^{226} \mathrm{Ra},{ }^{232} \mathrm{Th}$ and ${ }^{40} \mathrm{~K}(\mathrm{~Bq} \mathrm{~kg})$, respectively. The results of radium equivalent activities $\left(\mathrm{Ra}_{\mathrm{eq}}\right)$ for sediment are presented in Table 4. As noted in Table 4, the radium equivalent activity value varied from $39.07 \mathrm{~Bq} \mathrm{~kg}^{-1}$ to $97.59 \mathrm{~Bq} \mathrm{~kg}^{-1}$ with the average of $62.81 \mathrm{~Bq} \mathrm{~kg}^{-1}$. The determined average value were found to be less than the recommended maximum permissible value of $370 \mathrm{~Bq} \mathrm{~kg}^{-1}$ [24].

\subsubsection{External Hazard İndex $\left(\mathrm{H}_{\mathrm{ex}}\right)$}

The main aim of this index is to limit the radiation dose to dose equivalent limit of $1 \mathrm{mSvy}^{-1}$ [25]. $\mathrm{H}_{\mathrm{ex}}$ should not exceed the unity limit in order to ensure that the level of risk generated by the radiation is negligible. $\mathrm{H}_{\mathrm{ex}}$ was determined using the formula described below [26].

$$
H_{e x}=\frac{C_{R a}}{370}+\frac{C_{T h}}{259}+\frac{C_{K}}{4810} \leq 1
$$

Table 4 showed that the average hazard index values for all samples were less than unity, which revealed that there was no harm to the farmers and populations living in the area studied. 


\subsubsection{Absorbed dose rate in air (D)}

The gamma dose rate absorbed in outdoor air exposed at 1 meter above the surface by knowing the activity concentrations of ${ }^{226} \mathrm{Ra},{ }^{232} \mathrm{Th},{ }^{40} \mathrm{~K}$ and ${ }^{137} \mathrm{Cs}$ in the sediment can be determined using the formula defined below [22, 27]:

$D\left(n G y h^{-1}\right)=0.461 \times C_{R a}+0.623 \times C_{T h}+0.0417 \times C_{K}+0.1243 \times C_{C S}$

where $\mathrm{C}_{\mathrm{Ra}}, \mathrm{C}_{\mathrm{Th}}, \mathrm{C}_{\mathrm{K}}$ and $\mathrm{C}_{\mathrm{Cs}}$ are the activity concentration values (in $\mathrm{Bq} \mathrm{kg}{ }^{-1}$ ) of ${ }^{226} \mathrm{Ra},{ }^{232} \mathrm{Th},{ }^{40} \mathrm{~K}$ and ${ }^{137} \mathrm{Cs}$, respectively, in the sediment samples. The detected activity concentrations were converted into doses using dose conversion factors of $0.461,0.623,0.0417$ and 0.1243 for ${ }^{226} \mathrm{Ra}$, ${ }^{232} \mathrm{Th},{ }^{40} \mathrm{~K}$ and ${ }^{137} \mathrm{Cs}$, respectively [22]. Looking at Table 4, the determined values of absorbed gamma dose rate for the sediment samples ranged from 19.27 to $49.57 \mathrm{nGyh}^{-1}$ with an average value of $31.43 \mathrm{nGyh}^{-1}$. The determined average doses for all samples is lower than the world average value of $60 \mathrm{nGy} \mathrm{h}^{-1}$ [28].

\subsubsection{Annual effective dose equivalent (AEDE)}

The annual effective dose equivalent (AEDE) was determined using the equation given below [22]:

$A E D E\left(m S v y^{-1}\right)=D\left(n G y h^{-1}\right) \times 8760 h \times 0.7 S v G y^{-1} \times 0.2 \times 10^{-6}$

According to Table 4, the determined values of the annual effective dose for the sediment samples ranged from 0.024 and $0.061 \mathrm{mSvy}^{-1}$, with a mean value of $0.039 \mathrm{mSvy}^{-1}$ [22]. However, the determined mean dose values for all samples was lower than the recommended limit value of $0.080 \mathrm{mSvy}^{-1}$.

\subsubsection{Excess lifetime cancer risk (ELCR)}

The excess lifetime cancer risk (ELCR) values were determined with the help of the relation given below [22]:

$$
E L C R=A E D E \times D L \times R F
$$

DL Here is the average life expectancy (about 78 years in Turkey) [15] and RF are factors indicating the probability of a deadly carcinogen per sievert $\left(\mathrm{Sv}^{-1}\right)$. Because of stochastic effects, ICRP 60 considers 0.05 for public [29]. When Table 4 was examined, it was seen that the ELCR values ranged from $0.09 \times 10^{-3}$ to $0.24 \times 10^{-3}$ (with a mean value $0.15 \times 10^{-3}$ ). This average value of ELCR is less than the world average $\left(0.29 \times 10^{-3}\right)$ [27]. 
In addition, looking at Table 4, the average lifetime total dose rate was determined as $3.01 \mathrm{mSv}$. This determined mean value is lower than recommended maximum permissible value of 4.90 $\mathrm{mSv}[22]$.

Table 4. Radiological parameters of the sediment samples collected from the Borçka Dam Lake.

\begin{tabular}{|c|c|c|c|c|c|c|}
\hline $\begin{array}{c}\text { Sampling } \\
\text { location }\end{array}$ & Raeq $\left(\mathrm{Bq} \mathrm{kg}^{-1}\right)$ & $\mathrm{H}$ ex & $\mathrm{D}\left(\mathrm{nGy} \mathrm{h}^{-1}\right)$ & $\begin{array}{c}\mathrm{AEDE} \\
\left(\mathrm{mSv}{ }^{-1}\right)\end{array}$ & $\begin{array}{c}\text { Lifetime total } \\
\text { dose }(\mathrm{mSv})\end{array}$ & ELCR $\left(\times 10^{-3}\right)$ \\
\hline BS-1 & 79.33 & 0.21 & 39.55 & 0.049 & 3.78 & 0.19 \\
\hline BS-2 & 40.65 & 0.11 & 19.98 & 0.024 & 1.91 & 0.10 \\
\hline BS-3 & 39.07 & 0.11 & 19.27 & 0.024 & 1.84 & 0.09 \\
\hline BS-4 & 58.48 & 0.16 & 29.28 & 0.036 & 2.80 & 0.14 \\
\hline BS-5 & 61.72 & 0.17 & 30.90 & 0.038 & 2.96 & 0.15 \\
\hline BS-6 & 97.59 & 0.26 & 49.57 & 0.061 & 4.74 & 0.24 \\
\hline Min & $\mathbf{3 9 . 0 7}$ & $\mathbf{0 . 1 1}$ & $\mathbf{1 9 . 2 7}$ & $\mathbf{0 . 0 2 4}$ & $\mathbf{1 . 8 4}$ & $\mathbf{0 . 0 9}$ \\
\hline Max & $\mathbf{9 7 . 5 9}$ & $\mathbf{0 . 2 6}$ & $\mathbf{4 9 . 5 7}$ & $\mathbf{0 . 0 6 1}$ & $\mathbf{4 . 7 4}$ & $\mathbf{0 . 2 4}$ \\
\hline Mean & $\mathbf{6 2 . 8 1}$ & $\mathbf{0 . 1 7}$ & $\mathbf{3 1 . 4 3}$ & $\mathbf{0 . 0 3 9}$ & $\mathbf{3 . 0 1}$ & $\mathbf{0 . 1 5}$ \\
\hline
\end{tabular}

\subsection{Statistical Analyses}

Pearson's correlation coefficients were determined to evaluate the relationship between radionuclides and some physico-chemical parameters in sediment samples and given in Table 5. The correlation analysis revealed that $40 \mathrm{~K}$ was substantially correlated with $226 \mathrm{Ra}(\mathrm{r}=0.957$, $\mathrm{p}<0.01)$, $\mathrm{pH}$ was substantially correlated with $232 \mathrm{Th}(\mathrm{r}=-0.970, \mathrm{p}<0.01)$ and Silt + Clay was substantially correlated with Sand $(r=-1.000, p<0.01)$. Besides, TOC was moderately correlated with 232Th $(r=0.848, p<0.05)$ and 137Cs $(r=0.849, p<0.05)$, Depth was moderately correlated with $232 \mathrm{Th}(\mathrm{r}=0.827, \mathrm{p}<0.05)$ and $40 \mathrm{~K}(\mathrm{r}=0.844, \mathrm{p}<0.05)$ and $137 \mathrm{Cs}$ was moderately correlated with $232 \mathrm{Th}(\mathrm{r}=0.888, \mathrm{p}<0.05)$. The strong relationship between 226Ra and 40K shows that their origin and behavior in the lake is the same, while the weak positive relationship between $232 \mathrm{Th}$ and the other two radionuclides (226Ra and $40 \mathrm{~K}$ ) indicates that they may have the same origin but their behavior in the lake environment differ [30]. It seems that there is no clear relationship between $\mathrm{pH}$ and the activity concentrations of $226 \mathrm{Ra}, 40 \mathrm{~K}$ and $137 \mathrm{Cs}$ in the sediment of the dam lake, while there is a considerable negative relationship between $\mathrm{pH}$ of the sediment and the activity of $232 \mathrm{Th}$. For these relationships can be said that the radionuclides extracted from a leached sediment into the water in neutral and alkaline media could decrease and weaken the fixation of nuclides in the sediment [31]. The similar results of this study were consistent with the 
finding of literature [31-32] concerning about the effect of soil properties. In light of this information, it can be said that the activity levels of artificial and natural radionuclides decrease in sediment samples with increasing $\mathrm{pH}$. Although no significant correlation was found between 137Cs and depth, a positive correlation was found between the two parameters. This can be explained by the fact that $137 \mathrm{Cs}$ is correlated with the depth of the sediment, as expressed by Szarlowicz et al. (2018) [33]. The concentration of 137Cs varies depending on the particle size of the sediment, mineral composition, organic matter and total organic carbon content. The amount of total organic carbon was found to be important in the deposition of 137Cs radionuclides in sediments [14] and a significant relationship between the amount of total organic matter and 137Cs was reported in some studies in the literature [14, 34-35]. In this study, a positive correlation was found between the amount of total organic carbon and 137Cs radioisotope in accordance with the literature.

Table 5. Pearson correlation coefficients between radionuclides and some physico-chemical parameters in sediment samples.

\begin{tabular}{|c|c|c|c|c|c|c|c|c|c|}
\hline & ${ }^{226} \mathrm{Ra}$ & ${ }^{232} \mathrm{Th}$ & ${ }^{137} \mathrm{Cs}$ & ${ }^{40} \mathrm{~K}$ & $\mathrm{pH}$ & Sand & Silt+Clay & TOC & Depth \\
\hline${ }^{226} \mathrm{Ra}$ & 1 & & & & & & & & \\
\hline${ }^{232} \mathrm{Th}$ & 0.500 & 1 & & & & & & & \\
\hline${ }^{137} \mathrm{Cs}$ & 0.649 & $0.888^{*}$ & 1 & & & & & & \\
\hline${ }^{40} \mathrm{~K}$ & $0.957^{* *}$ & 0.501 & 0.582 & 1 & & & & & \\
\hline $\mathrm{pH}$ & -0.352 & $-0.970^{* *}$ & -0.758 & -0.391 & 1 & & & & \\
\hline Sand & -0.024 & -0.184 & -0.532 & 0.114 & 0.023 & 1 & & & \\
\hline Silt+Clay & 0.024 & 0.184 & 0.532 & -0.114 & -0.023 & $-1.000^{* * *}$ & 1 & & \\
\hline TOC & 0.181 & $0.848^{*}$ & $0.849^{*}$ & 0.184 & -0.800 & -.0577 & 0.577 & 1 & \\
\hline Depth & 0.809 & $0.827^{*}$ & 0.771 & $0.844^{*}$ & -0.748 & 0.059 & -0.059 & 0.530 & 1 \\
\hline
\end{tabular}

Correlation is significant at the 0.01 level (two-tailed).

Correlation is significant at the 0.05 level (two-tailed).

\section{CONCLUSION}

The activity values of ${ }^{226} \mathrm{Ra},{ }^{232} \mathrm{Th},{ }^{137} \mathrm{Cs}$ and ${ }^{40} \mathrm{~K}$ were determined in sediment samples collected from the Borçka Dam Lake using gamma ray spectroscopy. The mean activity concentrations of ${ }^{226} \mathrm{Ra},{ }^{232} \mathrm{Th},{ }^{137} \mathrm{Cs}$ and ${ }^{40} \mathrm{~K}$ were found to be $12.19 \mathrm{~Bq} \mathrm{~kg}^{-1}, 14.05 \mathrm{~Bq} \mathrm{~kg}^{-1}, 4.20 \mathrm{~Bq} \mathrm{~kg}^{-1}$ and $396.41 \mathrm{~Bq} \mathrm{~kg}^{-1}$, respectively. The results show that the mean activity concentration values of ${ }^{226} \mathrm{Ra},{ }^{232} \mathrm{Th}$ and ${ }^{40} \mathrm{~K}$ in the Borçka Dam Lake were lower than the world average values suggested by UNSCEAR. Also, the mean activity concentration of ${ }^{137} \mathrm{Cs}$ is lower than the results of previous studies in the literature. Additionally, the radiological hazard 
indices ( $\mathrm{Ra}_{\mathrm{eq}}, \mathrm{H}_{\mathrm{ex}}, \mathrm{D}, \mathrm{AEDE}$, and ELCR) were determined and compared with international permissible values, and the results were lower than the limit values. The data obtained can be used by the researchers as reference data for monitoring possible radioactive contamination of the Borçka Dam Lake in the future.

\section{Acknowledgments}

The author also would like to thank Associate Professor Kenan GEDIK for his contributions in collecting sediment samples.

\section{REFERENCES}

[1] Zorer Ö.S., Evaluations of environmental hazard parameters of natural and some artificial radionuclides in river water and sediments, Microchem. J., 145 (2019) 762-766.

[2] Papaefthymiou H., Athanasopoulos D., Papatheodorou G., Iatrou M., Geraga M., Christodoulou D., Kordella S., Fakiris E. and Tsikouras B., Uranium and other natural radionuclides in the sediments of a Mediterranean fjord-like embayment, Amvrakikos Gulf (Ionian Sea), Greece, J. Environ. Radioact., 122 (2013) 43-54.

[3] Ergül H.A., Belivermiş M., Kılıç Ö., Topcuoğlu S. and Çotuk Y., Natural and artificial radionuclide activity concentrations in surface sediments of Izmit Bay, Turkey, J. Environ. Radioact., 126 (2013) $125-132$.

[4] El-Taher A. and Madkour H.A., Distribution and environmental impacts of metals and natural radionuclides in marine sediments in-front of different wadies mouth along the Egyptian Red Sea Coast, Appl. Radiat. Isot., 69 (2011) 550-558.

[5] Otansev P., Taşkın H., Başsarı A. and Varinlioğlu A., Distribution and environmental impacts of heavy metals and radioactivity in sediment and seawater samples of the Marmara Sea, Chemosphere, 154 (2016) 266-275.

[6] Celik N., Cevik U., Celik A. and Koz B., Natural and artificial radioactivity measurements in Eastern Black Sea region of Turkey, J. Hazard. Mater., 162 (2009) 146-153.

[7] Aytas S., Yusan S., Aslani M.A., Karali T., Turkozu D.A., Gok C., Erenturk S., Gokce M. and Oguz K.F., Natural radioactivity of riverbank sediments of the Maritza and Tundja Rivers in Turkey, J. Environ. Sci. Heal. Part A, 47 (2012) 2163-2172.

[8] Eroğlu, H. and Kabadayi, Ö., Natural radioactivity levels in lake sediment samples, Radiat. Prot. Dosimetry, 156 (2013) 331-335.

[9] Kulahci F. and Doğru M., Physical and chemical investigation of water and sediment of the Keban Dam Lake, Turkey Part 1: Iso-curves of radioactivity, J. Radioanal. Nucl. Chem., 268 (2006) $517-$ 528.

[10] Kobya Y., Taşkın H., Yeşilkanat C.M., Varinlioğlu A. and Korcak S., Natural and artificial radioactivity assessment of dam lakes sediments in Çoruh River, Turkey, J. Radioanal. Nucl. Chem., 303 (2015) 287-295.

[11] Arıman S. and Gümüş H., Radioactivity levels and health risks due to radionuclides in the soil and sediment of mid-Black Sea: Kızılırmak Deltas-Turkey, Radiochim. Acta, 106 (2018) 927-937. 
[12] Baltas H., Sirin M., Dalgic G. and Cevik U., An overview of the ecological half-life of the ${ }^{137} \mathrm{Cs}$ radioisotope and a determination of radioactivity levels in sediment samples after Chernobyl in the Eastern Black Sea, Turkey, J. Mar. Syst., 177 (2018) 21-27.

[13] Gedik K., Terzi E. and Yesilcicek T., Biomonitoring of metal (oid)s in mining-affected Borcka Dam Lake coupled with public health outcomes, Hum. Ecol. Risk Assess. An Int. J., 24 (2018) 1-18.

[14] Kim Y., Kim K., Kang H.D., Kim W., Doh S.H., Kim D.S. and Kim B.K., The accumulation of radiocesium in coarse marine sediment: effects of mineralogy and organic matter, Mar. Pollut. Bull., 54 (2007) 1341-1350.

[15] Baltas H., Kiris E., Dalgic G. and Cevik U., Distribution of ${ }^{137} \mathrm{Cs}$ in the Mediterranean mussel (Mytilus galloprovincialis) in Eastern Black Sea Coast of Turkey, Mar. Pollut. Bull., 107 (2016) 402-407.

[16] Baltas H., Kiris E., Ustabas I., Yilmaz E., Sirin M., Kuloglu E. and Gunes B.E., Determination of natural radioactivity levels of some concretes and mineral admixtures in Turkey, Asian J. Chem., 26 (2014) 3946-3952.

[17] Baltas, H., Kiris, E. and Sirin M., Determination of radioactivity levels and heavy metal concentrations in seawater, sediment and anchovy (Engraulis encrasicolus) from the Black Sea in Rize, Turkey, Mar. Pollut. Bull., 116 (2017) 528-533.

[18] Currie L.A., Limits for qualitative detection and quantitative determination. Application to radiochemistry, Anal. Chem., 40 (1968) 586-593.

[19] Caridi F., Marguccio S., Belvedere A. and Belmusto G., Measurements of gamma radioactivity in river sediment samples of the Mediterranean Central Basin, Am. J. Condens. Matter Phys., 5 (2015) $61-68$.

[20] Wang J., Du J. and Bi Q., Natural radioactivity assessment of surface sediments in the Yangtze Estuary, Mar. Pollut. Bull., 114 (2017) 602-608.

[21] Ramasamy V., Paramasivam K., Suresh G. and Jose M.T., Role of sediment characteristics on natural radiation level of the Vaigai river sediment, Tamilnadu, India, J. Environ. Radioact., 127 (2014) 6474.

[22] U.N.S.C. on the E. of A. Radiation, Sources and effects of ionizing radiation UNSCEAR 2000 report to the General Assembly, with scientific annexes Volume I: Sources, (2000).

[23] Elsaman R., Omer M.A.A., Seleem E.M.M. and El-Taher A., Natural Radioactivity Levels and Radiological Hazards in Soil Samples Around Abu Karqas Sugar Factory, J. Environ. Sci. Technol., 11 (2018) 28-38.

[24] Beretka J. and Matthew P.J., Natural radioactivity of Australian building materials, industrial wastes and by-products, Health Phys., 48 (1985) 87-95.

[25] (ICRP) I.C. on R. Protection, Protection against radon-222 at home and at work, International Commission on Radiological Protection, (1992).

[26] SureshGandhi M., Ravisankar R., Rajalakshmi A., Sivakumar S., Chandrasekaran A. and Anand D.P., Measurements of natural gamma radiation in beach sediments of north east coast of Tamilnadu, India by gamma ray spectrometry with multivariate statistical approach, J. Radiat. Res. Appl. Sci., 7 (2014) 7-17. 
[27] Taskin H., Karavus M., Ay P., Topuzoglu A., Hidiroglu S. and Karahan G., Radionuclide concentrations in soil and lifetime cancer risk due to gamma radioactivity in Kirklareli, Turkey, J. Environ. Radioact., 100 (2009) 49-53.

[28] Kayakökü H. and Doğru M., Radioactivity analysis of soil samples taken from the western and northern shores of Lake Van, Turkey, Appl. Radiat. Isot., 128 (2017) 231-236.

[29] I.C. on R. Protection, ICRP Publication 60: 1990 Recommendations of the International Commission on Radiological Protection, Elsevier Health Sciences, (1991).

[30] Isinkaye M.O. and Emelue H.U., Natural radioactivity measurements and evaluation of radiological hazards in sediment of Oguta Lake, South East Nigeria, J. Radiat. Res. Appl. Sci., 8 (2015) 459-469.

[31] Tsai T.L., Liu C.C., Chuang C.Y., Wei H.J. and Men L.C., The effects of physico-chemical properties on natural radioactivity levels, associated dose rate and evaluation of radiation hazard in the soil of Taiwan using statistical analysis, J. Radioanal. Nucl. Chem., 288 (2011) 927-936.

[32] Skarlou V., Papanicolaou E.P. and Nobeli C., Soil to plant transfer of radioactive cesium and its relation to soil and plant properties, Geoderma, 72 (1996) 53-63.

[33] Szarlowicz K., Reczynski W., Czajka A., Spyt B. and Szacilowski G., Comprehensive study of the mountainous lake sediments in relation to natural and anthropogenic processes and time (Mały Staw Lake, Poland), Environ. Sci. Pollut. Res., 25 (2018) 3335-3347.

[34] Park G., Lin X.J., Kim W., Kang H.D., Lee H.L., Kim Y., Doh S.H., Kim D.S., Yun S.G. and Kim C.K., Properties of ${ }^{137} \mathrm{Cs}$ in marine sediments off Yangnam, Korea, J. Environ. Radioact., 77 (2004) 285-299.

[35] Kim Y., Cho S., Kang H.D., Kim W., Lee H.R., Doh S.H., Kim K., Yun S.G., Kim D.S. and Jeong G.Y., Radiocesium reaction with illite and organic matter in marine sediment, Mar. Pollut. Bull., 52 (2006) 659-665. 